\title{
CORRIGENDUM
}

\section{Life satisfaction among older people in Italy in a gender approach - CORRIGENDUM}

\section{SILVIA MEGGIOLARO and FAUSTA ONGARO}

doi:10.1017/So144686X14000646, published online by Cambridge University Press 3 July 2014.

In this article the Acknowledgements section was omitted in error and appears below:-

This paper was prepared within the framework of the research programme "The Italian families between tradition and innovation. New types, new challenges and new opportunities" supported by the University of Padova in the ambit of the 2013 University Research Projects, grant number CPDA 139158 . The authors are also grateful to the anonymous reviewers for their helpful comments and suggestions to improve the manuscript.

\section{REFERENGE}

Meggiolaro, S. and Ongaro, F. 2014. Life satisfaction among older people in Italy in a gender approach. Ageing and Society, published by Cambridge University Press 3 July 2014. doi:10.1017/So144686X1400o646. 